\section{UMH 1203, a Multiple Virus-resistant Fresh-market Tomato Breeding Line for Open-field Conditions}

\author{
Santiago García-Martínez, Adrián Grau, Aranzazu Alonso, \\ Fernando Rubio, Manuel Valero, and Juan J. Ruiz ${ }^{1}$ \\ Department of Applied Biology, Universidad Miguel Hernández, Escuela \\ Politécnica Superior de Orihuela, Carretera de Beniel, km. 3,2, 03312, \\ Orihuela, Spain
}

Additional index words. ToMV, TSWV and TYLCV, Tm-2a, Sw-5, Ty-1

\begin{abstract}
'De la Pera' is a tomato landrace that is very popular in a limited area in southeastern Spain as a result of its organoleptic fruit quality. Its cultivation is restricted to a small area in the Segura River region in Alicante. Fruits have a juicy and firm texture, a high proportion of seeds and mucilage, and are strongly flavored. Fruits weigh between 75 and $125 \mathrm{~g}$, varying from elongated-oval to bell shape with dark green shoulders and without ribs. However, like most tomato landraces, De la Pera cultivars are highly susceptible to several viruses such as Tomato mosaic virus (ToMV), Tomato spotted wilt virus (TSWV), and Tomato yellow curl virus (TYLCV) (Ruiz et al., 2005). A breeding program for the introgression of resistance to ToMV, TSWV, and TYLCV into several tomato landraces has been carried out over the last 10 years at Miguel Hernández University (Spain). Breeding line UMH 1203 is the second release from this breeding program (García-Martínez et al., 2011). UMH 1203 has medium-sized fruits (70 to $100 \mathrm{~g}$ ) and organoleptic characteristics similar to those of the landrace. Under greenhouse cropping, this homozygous breeding line suffers from a yield penalty, but its performance in open-field conditions is similar to the original landrace.
\end{abstract}

\section{Origin}

Breeding line UMH 1203 has been developed following the same breeding scheme as that used for the development of UMH 1200 (García-Martínez et al., 2011). UMH 1203 has been obtained by crossing a 'De la Pera' line (accession P21, previously selected for fruit morphological characteristics, high yield, and uniformity) with the commercial $\mathrm{F}_{1}$ cultivar Anastasia (Seminis Vegetable Seeds, Saint Louis, MO) followed by six generations of backcrossing to the 'De la Pera' line. Anastasia was used as the donor parent of

Received for publication 14 Oct. 2011. Accepted for publication 10 Nov. 2011.

This work was partially supported by the Spanish MICINN through projects AGL2002-03329, AGL2005-03946, and AGL2008-03822.

${ }^{1}$ To whom reprint requests should be addressed; e-mail juanj.ruiz@umh.es. self-pollination. UMH 1203 resistances have been demonstrated in several field and greenhouse trials. In addition, ToMV and TSWV resistances were verified by mechanical inoculation assays, and tolerance to TYLCV has been demonstrated in several naturally infested fields.

\section{Description and Performance}

UMH 1203 has indeterminate growth with intermediate foliage density. The green shoulders of UMH 1203 fruits (Fig. 1) are frequently less intense than those of the original landrace fruits. Ripe fruits separate easily from pedicels during harvest, as is the case with the line P21. In trials carried out in 2009, 2010, and 2011, no significant differences in yield were found between $\mathrm{UMH}$ 1203 and P21 in the open-field crops (Table 1). However, UMH 1203 showed a very important yield decrease in the two greenhouse trials. Average fruit weight of UMH 1203 was similar to that of the traditional cultivar and no significant differences were found for the titratable acidity between the breeding line and the original line, except in the 2011 open-field trial. In two of the trials, significant differences were detected for soluble solids content, but differences were not consistent, because in the 2009 open-field trial, the line P21 reached slightly higher values than UMH 1203, but the opposite result was shown in the 2010 trial. The results of the organoleptic test presented in Table 2 also suggest a high level of similarity between the two lines for sensory aspects of fruit quality. Significant differences between the

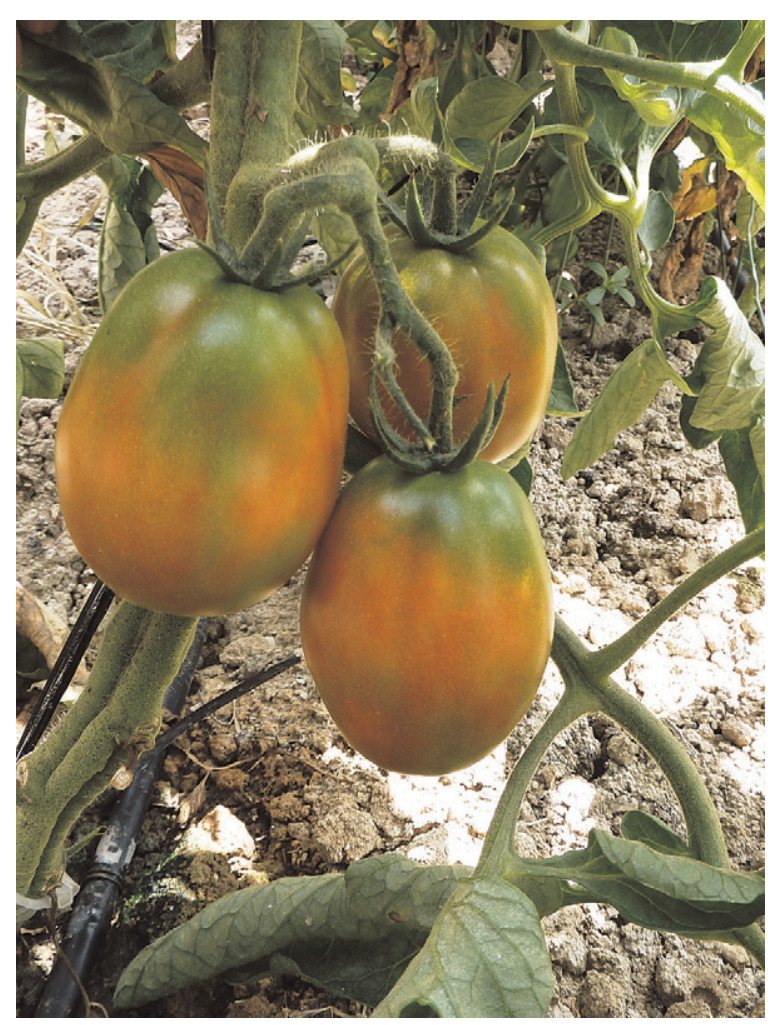

Fig. 1. Fruits of UMH 1203. 
Table 1. Yield traits, titratable acidity (TA), and soluble solids concentration (SSC) of the breeding line UMH 1203, the 'De la Pera' landrace (accession P21), and Boludo F , grown in 2009, 2010, and 2011 in the open field and in 2010 and 2011 under greenhouse in the spring to summer crop cycle.

\begin{tabular}{|c|c|c|c|c|c|}
\hline & $\begin{array}{l}\text { Marketable yield } \\
(\mathrm{kg} / \text { plant })^{\mathrm{z}}\end{array}$ & $\begin{array}{l}\text { Avg fruit } \\
\text { wt }(g)^{z}\end{array}$ & $\begin{array}{c}\text { Fruit number } \\
\text { per plant }^{z}\end{array}$ & TA $(g / 100 g)^{y}$ & SSC $\left({ }^{\circ} \text { Brix }\right)^{y}$ \\
\hline \multicolumn{6}{|l|}{ Open field 2009} \\
\hline UMH 1203 & $1.85 \mathrm{a}^{\mathrm{x}}$ & $82 \mathrm{a}$ & $21.9 \mathrm{a}$ & $0.51 \mathrm{a}$ & $4.93 \mathrm{a}$ \\
\hline Accession P21 & $1.95 \mathrm{a}$ & $88 \mathrm{a}$ & $22.4 \mathrm{a}$ & $0.51 \mathrm{a}$ & $5.18 \mathrm{~b}$ \\
\hline Boludo $\mathrm{F}_{1}$ & $2.92 \mathrm{~b}$ & $97 \mathrm{~b}$ & $30.0 \mathrm{~b}$ & $0.60 \mathrm{~b}$ & $4.74 \mathrm{a}$ \\
\hline \multicolumn{6}{|l|}{ Open field 2010} \\
\hline UMH 1203 & $2.71 \mathrm{a}$ & $91 \mathrm{a}$ & $30.0 \mathrm{a}$ & $0.30 \mathrm{a}$ & $4.49 \mathrm{~b}$ \\
\hline Accession P21 & $2.65 \mathrm{a}$ & $87 \mathrm{a}$ & $32.6 \mathrm{a}$ & $0.32 \mathrm{a}$ & $4.10 \mathrm{a}$ \\
\hline Boludo $\mathrm{F}_{1}$ & $4.48 \mathrm{~b}$ & $136 \mathrm{~b}$ & $33.9 \mathrm{a}$ & $0.54 \mathrm{~b}$ & $5.10 \mathrm{c}$ \\
\hline \multicolumn{6}{|l|}{ Greenhouse 2010} \\
\hline UMH 1203 & $2.26 \mathrm{a}$ & $78 \mathrm{a}$ & $29.2 \mathrm{a}$ & $0.30 \mathrm{a}$ & $4.05 \mathrm{a}$ \\
\hline Accession P21 & $3.72 \mathrm{~b}$ & $106 \mathrm{~b}$ & $35.4 \mathrm{~b}$ & $0.30 \mathrm{a}$ & $3.89 \mathrm{a}$ \\
\hline Boludo $\mathrm{F}_{1}$ & $4.84 \mathrm{c}$ & $101 \mathrm{~b}$ & $50.2 \mathrm{c}$ & $0.48 \mathrm{~b}$ & $4.57 \mathrm{~b}$ \\
\hline \multicolumn{6}{|l|}{ Open field 2011} \\
\hline UMH 1203 & $2.76 \mathrm{a}$ & $89 a$ & $34.1 \mathrm{a}$ & $0.45 \mathrm{~b}$ & $4.53 \mathrm{a}$ \\
\hline Accession P21 & $3.14 \mathrm{a}$ & $87 \mathrm{a}$ & $42.3 \mathrm{~b}$ & $0.34 \mathrm{a}$ & $4.47 \mathrm{a}$ \\
\hline Boludo $\mathrm{F}_{1}$ & $5.30 \mathrm{~b}$ & $137 \mathrm{~b}$ & $48.4 \mathrm{~b}$ & $0.75 \mathrm{c}$ & $4.52 \mathrm{a}$ \\
\hline \multicolumn{6}{|l|}{ Greenhouse 2011} \\
\hline UMH 1203 & $1.40 \mathrm{a}$ & $71 \mathrm{a}$ & $16.0 \mathrm{a}$ & $0.43 \mathrm{a}$ & $5.23 \mathrm{~b}$ \\
\hline Accession P21 & $2.79 \mathrm{~b}$ & $72 \mathrm{a}$ & $34.7 \mathrm{~b}$ & $0.48 \mathrm{a}$ & $5.17 \mathrm{~b}$ \\
\hline Boludo $\mathrm{F}_{1}$ & $5.12 \mathrm{c}$ & $95 \mathrm{~b}$ & $50.7 \mathrm{c}$ & $0.74 \mathrm{~b}$ & 4,61 a \\
\hline
\end{tabular}

${ }^{\mathrm{z}}$ Mean of six plants per plot for two replicates.

${ }^{y}$ Mean of six fruits per plot for two replicates.

${ }^{x}$ Mean values in a column followed by a different letter are significantly different according to the Duncan's multiple range test $(P<0.05)$.

Table 2. Comparative sensory analysis of UMH 1203 and accession P21 grown in the open field in 2011 in the spring to summer crop cycle. ${ }^{\mathrm{z}}$

\begin{tabular}{|c|c|c|c|c|}
\hline & External appearance & Flavor & Texture & Overall acceptability \\
\hline Line & Mean $^{\mathrm{y}}$ & Mean & Mean & Mean \\
\hline UMH 1203 & $3.8 \pm 0.12$ & $3.2 \pm 0.13$ & $3.4 \pm 0.10$ & $3.2 \pm 0.11$ \\
\hline Accession P21 & $3.2 \pm 0.08$ & $3.4 \pm 0.20$ & $3.5 \pm 0.13$ & $3.3 \pm 0.09$ \\
\hline Significance & $*$ & NS & NS & NS \\
\hline
\end{tabular}

${ }^{\mathrm{z} F o r}$ sensory analysis, fruits were washed and cut into wedges.

${ }^{\mathrm{y}}$ Each value is the mean ( $\pm \mathrm{SE}$ ) of the scores of 33 untrained tasters on a 1 (very bad) to 5 (very good) scale. NS, *Non-significant or significant at $P \leq 0.05$ according to the $t$ test.

breeding line UMH 1203 and line P21 were detected for external appearance, but not for flavor, texture, and overall acceptability. UMH 1203 showed higher values for external appearance than $\mathrm{P} 21$, but the original line received slightly higher scores for flavor, texture, and overall acceptability. The mair goal of the breeding program was to obtain a breeding line with virus resistance that maintains the fruit morphological and organoleptic characteristics of the 'De la Pera' landrace.
Use

Breeding line UMH 1203 has genetic tolerance/resistance to ToMV, TSWV, and TYLCV, the three most important viruses in tomato in southeastern Spain. The incidence of these viruses in tomato landraces greatly reduces the profits obtained by farmers, and even makes their cultivation nonviable in many areas, especially in open-field conditions. The breeding line is available for open-air cropping where the viruses' incidence is especially intense, allowing farmers to obtain an acceptable harvest. This breeding line may also be used in breeding programs to facilitate the introgression of the resistance genes into other landraces or heirloom tomatoes.

\section{Availability}

Small trial seed samples of the UMH 1203 breeding line are available for research purposes (contact the authors).

\section{Literature Cited}

García-Martínez, S., A. Grau, A. Alonso, F. Rubio, M. Valero, and J.J. Ruiz. 2011. UMH 1200, a breeding line within the muchamiel tomato type, resistant to three viruses. HortScience 46:1054-1055.

García-Martínez, S., C. Sánchez, J. Castelló, A. Grau, M. Valero, A. Ferrández, and J.J. Ruiz. 2003. Empleo de marcadores moleculares para la introducción múltiple de genes de resistencia a virosis (ToMV, TSWV y TYLCV) en variedades tradicionales de tomate alicantinas. Agrícola Vergel 255:140-143.

Pérez de Castro, A., J.M. Blanca, M.J. Díez, and F. Nuez. 2007. Identification of a CAPS marker tightly linked to the Tomato yellow leaf curl disease resistance gene $T y-1$ in tomato. Eur. J. Plant Pathol. 117:347-356.

Ruiz, J.J., S. García-Martínez, B. Picó, M. Gao, and C.F. Quiros. 2005. Genetic variability and relationship of closely related Spanish traditional $\mathrm{M}$. varieties of tomato as detected by SRAP and SSR markers. J. Amer. Soc. Hort. Sci. 130:88-94. 